Journal of Telenursing (JOTING)

Volume 2, Nomor 1, Juni 2020

e-ISSN: 2684-8988

p-ISSN: 2684-8996

DOI: https://doi.org/10.31539/joting.v2i1.1097

\title{
KOMPRES NaCI 0,9\% DALAM UPAYA MENURUNKAN NYERI POST INSERSI AV FISTULA PADA PASIEN GAGAL GINJAL KRONIK
}

\author{
Isnayati ${ }^{1}$, Suhatridjas ${ }^{2}$ \\ Akademi Perawat Pelni Jakarta ${ }^{1,2}$ \\ pelniisnayati@yahoo.com ${ }^{1}$
}

\begin{abstract}
ABSTRAK
Tujuan penelitian untuk mengetahui gambaran analisis Kompres $\mathrm{NaCl}$ 0,9\% terhadap menurunkan nyeri post insersi AV Fistula pasien gagal ginjal kronis selama hemodialisa. Desain penelitian merupakan metode penelitian deskriptif sederhana dengan pendekatan study kasus dan pemberian terapi kompres $\mathrm{NaCl} 0,9 \%$. Hasil penelitian selama dilakukan kompres terjadi penurun nyeri pada subjek I dan subjek II, tidak terjadi alergi, kedua subjek terlihat nyaman, tidak ada keluhan nyeri bertambah, tidak ada gestur atau ekspresi yang menunjukan menahan nyeri berat ketika dilakukan kompres. Keluhan nyeri yang di rasakan kedua subjek dari jam pertama hingga jam ke empat selalu mengalami pemunurun skala nyeri. Simpulan, terdapat penurunan skala nyeri pada subjek I dan subjek II antar 2-1 setiap di lakukan kompres selama 4 kali pertemuan.
\end{abstract}

Kata Kunci : Hemodialisa, Insersi AV Fistula, Kompres $\mathrm{NaCl}$ 0,9\%, Nyeri

\section{ABSTRACT}

The study aimed to determine the description of the analysis of $0.9 \% \mathrm{NaCl}$ compresses to reduce post-Fertula $A V$ insertion pain in patients with chronic renal failure during hemodialysis. The research design is a simple descriptive research method with a case study approach, and administration of $0.9 \% \mathrm{NaCl}$ compress therapy. The study results during the compress pain reduction occurred in the subject I and subject II; there was no allergy, both questions looked comfortable, there were no complaints of increased pain, no gestures or expressions that showed massive pain when compressed. Complaints of pain felt by the two subjects from the first hour to the fourth hour always experience a decrease in pain scale. In conclusion, there is a decrease in pain scale in question I and subject II between 2-1 every time it is compressed for four meetings.

Keywords: Hemodialysis, AV Fistula Insertion, 0.9\% NaCl Compress, Pain

\section{PENDAHULUAN}

Gagal ginjal kronik (GGK) atau disebut juga penurunan fungsi ginjal irreversible dan progresif merupakan suatu proses patofisiologi dengan penyebab yang beragam, yang mengakibatkan penuruan fungsi ginjal, biasanya berakhir dengan gagal ginjal (Wijaya \& Padila, 2019). Hal ini menyebabkan ketidak mampuan ginjal untuk membuang racun, produk sisa serta tidak mampu mempertahankan metabolisme, keseimbangan cairan dan elektrolit (Manus et al., 2015). Hal ini juga menyebabkan uremia dengan gejala mual sampai muntah, kehilangan nafsu makan atau penurunan berat badan, sering mengalami kram pada bagian kaki, sulit konsentrasi, mengalami 
kelelahan ekstrim (fatigue), yang ditandai dengan adanya protein dalam urin serta penurunan laju filtrasi glomerulus, berlangsung lebih dari 3 bulan (Padila, 2012; LeMone \& Bauldof, 2016).

Berdasarkan estimasi World Health Organization, secara global lebih dari 500 juta orang mengalami penyakit gagal ginjal kronis, sekitar 1,5 juta orang harus menjalani hidup bergantung cuci darah (Hemodialisa). Di negara maju, angka penderita gangguan ginjal cukup tinggi. Di Amerika Serikat misalnya 26 juta orang dewasa mengalami kegagalanmfungsi ginjalnya dan jutaan lainnya berada pada peningkatan risiko (National Kidney Foundation, 2015).

Sebanyak 2.786.000 orang, tahun 2012 sebanyak 3.018.860 orang dan tahun 2013 sebanyak 3.200.000 orang, berdasarkan hasil survei dari indonesia renal registry (2017) menuliskan bahwa peningkatan jumlah pasien baru yang melakukan dialisis pada tahun 2017 sebanyak 30,831 pasien baru yang mendaftar di rumah sakit di seluruh rumh sakit yang menyediakan layanan hemodialisa. Sedangkan di DKI Jakarta pada tahun 2017 jumlah pasien baru di rumah sakit yang menyediakan layanan hemodialisa sebanyak 2973 pasien baru di tahun 2017. Berdasarkan data Indonesian Renal Registry (IRR) (2016) sebanyak 98\% penderita gagal ginjal menjalani terapi hemodialisis.

Pravelensi gagal ginjal Data Riset Kesehatan Dasar tahun 2018 menunjukkan prevalensi penderita gagal ginjal meningkat sebesar $2 \%$ atau 2 per 100 penduduk ditahun 2013 menjadi 3,8\% pada tahun 2018 (Kemenkes,RI, 2018), dan proporsi pernah/sedang cuci darah pada penduduk berumur lebih dari 15 tahun yang pernah didiagnosa penyakit gagal ginjal kronik propinsi DKI menempati ururan pertama diikuti Bali dan DI Yogyakarta (Riskesdas, 2018).

Penyakit gagal ginjal kronis stadium akhir berarti ginjal sudah tidak berfungsi lagi, diperlukan cara untuk membuang zat-zat racun dari tubuh dengan terapi pengganti ginjal yaitu dengan cuci darah (Hemodialisis), Continous Ambulatory Peritoneal Dialysis (CAPD), dan pencangkokan ginjal (Transplantasi ginjal). Dari terapi tersebut hemodialisa merupakan terapi pengganti ginjal yang paling banyak digunakan di Indonesia. Hemodialisis adalah salah satu terapi pengganti ginjal yang menggunakan alat khusus dengan tujuan mengeluarkan racun atau toksin uremik dan mengatur cairan akibat penurunan laju filtrasi glomerulus dengan mengambil alih fungsi ginjal yang menurun (Djarwoto, 2018). Hemodialisis dilakukan dengan cara mengalirkan darah ke dalam tabung ginjal buatan yang bertujuan untuk mengeliminasi sisa-sisa metabolisme protein dan elektrolit antara kompartemen dialisat melalui membran semi permeable. (Manus et al., 2015).

Berdasarkan hasil survei dari Indonesia Renal Registry (2017) peningkatan jumlah pasien baru yang melakukan dialisis pada tahun 2017 sebanyak 30,831 pasien baru yang mendaftar di rumah sakit di seluruh rumah sakit yang menyediakan layanan hemodialisa. Sedangkan di DKI Jakarta pada tahun 2017 jumlah pasien baru di rumah sakit yang menyediakan layanan hemodialisa sebanyak 2973 pasien baru di tahun 2017. Berdasarkan data Indonesian Renal Registry (IRR) (2016) sebanyak 98\% penderita gagal ginjal menjalani terapi hemodialisis.

Pasien gagal ginjal yang menjalani hemodialisa dapat dilakukan melalui beberapa akses diantaranya melalui arteriovenosa fistula ( $A V$ Shunt), arteriovenosa fistula menjadi salah satu standar untuk akses vaskular pada pasien yang menjalani terapi hemodialisa. di mana pada prosedur ini di lakukan penusukan pada AV fistula. Kanulisasi adalah suatu tindakan menusukan jarum melalui kulit menuju pembuluh 
darah (AV Shunt atau Femoral) sebagai sarana untuk menghubungkan antara sirkulasi vaskular dan mesin dialisa selama proses hemodialisa (Endiyono, 2017).

Kanulisasi merupakan prosedur yang menimbulkan masalah fisik berupa rasa nyeri akibat penusukan pada arteriovenosa fistula, hal ini disebabkan karena kanul yang digunakan berukuran besar, dan rasa nyeri dapat dirasakan pasien selama pasien melakukan hemodialisis (Endiyono.2017). Respon nyeri merupakan pengalaman sensoris dan emosional yang tidak menyenangkan, hal ini disebabkan karena trauma atau kerusakan jaringan dan berisfat individual, sehingga diperlukan pengkajian yang yang cermat dan teliti.

Pengelolaan keperawatan pada pasien yang mengalami nyeri dilakukan melalui pendekatan proses keperawatan meliputi pengkajian dari pengakuan dan penerimaan nyeri pasien yang sangat individual. Serta dikaji pula sumber nyeri, interval nyeri secara teratur. Dalam perencanaan keperawatan melibatkan antardisiplin untuk mengelola nyeri, selain respon dan efek samping pengobatan, pendidikan kesehatan efektivitas strategi perencanaan keperawatan dapat pula menurunkan nyeri. Pengkajian yang teliti dan cermat untuk mengetahui skala nyeri sangat dibutuhkan agar rasa nyeri dapat diatasi dengan tindakan yang tepat (Pranowo et al., 2016). Beberapa penelitian telah menunjukan bahwa meskipun nyeri telah dikelola dengan baik, kira-kira $70 \%$ pasien yang mengalami nyeri akut sedang berlanjut menjadi nyeri akut hebat. Selain itu juga, survey mengindikasikan bahwa lebih dari $86 \%$ pasien mengalami nyeri sedang ke nyeri hebat meskipun analgesik ditingkatkan dan dapat menyebabkan efek samping yang dapat menimbulkan dampak fisiologis terhadap sistem organ dan psikologis pasien (LeMone \& Bauldof, 2016).

Pemberian kompres $\mathrm{NaCl} \quad 0,9 \%$ dipandang efektif dalam membantu mengendalikan nyeri, stimulasi dingin pada kulit akan menurunkan konduksi impuls serabut syaraf sensoris nyeri, sehingga rangsangan nyeri menuju hipotalamus akan dihambat dan diterima lebih lama (Evangeline, 2015).

$\mathrm{NaCl} 0,9 \%$ merupakan cairan isotonis yang bersifat fisiologis, non toksik dan tidak menimbulkan hipersensitivitas sehingga aman digunakan untuk tubuh dalam kondisi apapun. $\mathrm{NaCl}$ 0,9\% merupakan larutan isotonis aman untuk tubuh, tidak iritan, melindungi granulasi jaringan dari kondisi kering, menjaga kelembaban sekitar luka dan membantu luka menjalani proses penyembuhan luka. Selain itu $\mathrm{NaCl} 0,9 \%$ memiliki respon anti inflamasi sehingga dapat menurunkan gejala nyeri dan eritema yang timbul pada luka, serta meningkatkan aliran darah menuju area luka, sehingga mempercepat proses penyembuhan luka.

Menurut hasil penelitian yang di lakukan Endiyono (2017) menujukan bahwa pemberian kompres dingin pada saat penusukan AV fistula menujukan penurunan skala nyeri di bandingkan sebelum di lakukan intervensi. Penelitian yang di lakukan Fauji (2017) dengan hasil pemberian kompres $\mathrm{NaCl} 0,9 \%$ lebih efektif dalam menurunkan intensitas nyeri setelah insersi pada pasien hemodialisa. Menurut penelitian yang dilakukan oleh Pranowo et al., (2016) ada perbedaan skala nyeri yang bermakna antara sebelum pemberian kompres dan setelah pemberian kompres setelah kanulasi (inlet akses femoral) hemodialisis. Pasien yang menjalani hemodialisa perlu diberikan tindakan kompres menggunakan NaCL 0,9\% setelah kanulisa, diarea sekitar insersi untuk mengurangi nyeri selama pasien menjalani hemodialisa. 


\section{METODE PENELITIAN}

Metode yang digunakan dalam penelitian ini metode penelitian deskriptif sederhana dengan pendekatan studi kasus, yang mencakup pengkajian satu unit penelitian secara intensif, pada satu pasien, keluarga, kelompok, komunitas, atau institusi dengan jumlah subyek cenderung sedikit, tetapi jumlah variabel yang diteliti sangat luas.

Penelitian ini peneliti melakukan pemberian kompres dengan NaCL 0,9\% pada pasien gagal ginjal kronis yang menjalani hemodialisa yang dilakukan penusukan kanulasi (inlet akses femoral) untuk mengetahui penurunan tingkat nyeri, melibatkan 2 subjek yaitu dua pasien gagal ginjal kronis yang sedang menjalani hemodialisa.

Desain rancangan yang dipergunakan yaitu pre and post test group, dengan menilai intensitas sekala nyeri di sekitar area insersi kanula sebelum dan sesudah diberikan intervensi kompres dengan NaCL $0,9 \%$ pada pasien gagal ginjal kronis yang menjalani hemodialisa yang mendapat intervensi penusukan kanulasi (inlet akses femoral.

Gambaran skema penelitian yang dilakukan yaitu : A1 ---- B ----- A2

$\mathrm{A} 1=$ Pengukuran sekala nyeri sebelum dilakukan intervensi kompres dengan NaCL $0,9 \%$

$\mathrm{B}=$ Intervensi kompres NaCL $0,9 \%$

A2 = Pengukuran sekala nyeri setelelah dilakukan intervensi kompres NaCL 0,9\%

Pemberian kompres NaCL 0,9\% setelah kanulasi (inlet akses femoral) dengan secara purposive random sampling berdasarkan kriteria yang ditentukan. yaitu kriteria ketentuan yang diharapkan dan sample dipilih berdasarkan keinginan peneliti. Unit sampling diseleksi untuk tujuan tertentu, oleh karena itu digunakan istilah purposeful atau purposive. Pada penelitian ini peneliti melakukan intervensi pemberian kompres NACL 0,9 \% setelah kanulasi (inlet akses femoral)) untuk mengurangi nyeri, terhadap dua Subjek yang sedang menjalani hemodialisa dengan karakteristik tertentu yang dibuat peneliti sendiri dalam kriteria inklusi dan eklusi.

Kriteria inklusi yaitu pasien yang bersedia untuk mengikuti penelitian dan kooperatif, pasien yang menjalani hemodialisa 2 kali dalam seminggu, pasien yang mengunakan akses Vaskular ( $A V$ Fistula), pasien yang mengalami nyeri setelah di lakukan Insersi pada AV fistula saat hemodialisa, pasien dengan skala nyeri ringan (1-3 dari 1-10), Keadaan umum sedang, kesadaran composmentis, pasien dengan jenis kelamin perempuan, kelompok usia middle age (45-59 tahun) sedangkan Kriteria Eksklusi, Pasien Gagal Ginjal Kronis yang melakukan Hemodialisa dengan akses AV Fistula tidak mengalami nyeri setelah Insesi pada AV Fistula saat di lakukan Hemodialisa, pasien tidak menggunakan akses vaskular AV Fistula, pasien dengan keadaan umum berat, pasien dengan usia di bawah 45 tahun atau lebih dari 60 tahun, Pasien dengan skla nyeri diatas 3. Pasien dengan psikologi tidak setabil (Depresi).

Fokus studi pada kajian utama dari masalah yang akan dijadikan titik acuan penelitian. Fokus studi dari penelitian ini adalah pemberian kompres menggunakan $\mathrm{NaCL} 0,9 \%$ setelah kanulasi (inlet akses femoral) terhadap penurunan nyeri pada pasien yang sedang menjalani hemodialisa. 


\section{HASIL PENELITIAN}

Kondisi Sebelum Dilakukan Intervensi

Subjek 1

Setelah dilakukan wawancara dan pengkajian pada subjek I didapatkan hasil yaitu kesadaran komposmentis, subjek I mengatakan menjalani Hemodialisa semenjak 5 tahun yang lalu lalu, sebelumnya 15 tahun yang lalu subjek mengalami peningkatan kadar gula darah, dengan hasil tertinggi 432, setelah sembuh pasien tidak pernah kontrol dan mengkonsumsi obat gula. Sejak enam tahun yang lalu subjek1 dinyatakan menderita gagal ginjal, dan harus dilakukan hemodialisa. Keluhan yang dirasakan saat ini badan lemas, kadang - kadang terasa pusing, pucat (+), distensi vena jugularis $(+)$, konjungtiva terlihat anemis, muka sembab, perut rasa bagah, kembung $(+)$, kulit kering, bersisik dan kehitaman, BAK kurang dari $200 \mathrm{cc}$ perhari.

Subjek1 terpasang seminosan sejak 5 tahun yang lalu, sebelumnya subjek menggunakan CDL sampai 2 kali buka pasang karena terjadi infeksi dan saat Hemodialisa terkadang tidak berjalan lancer. Terdapat pelebaran pembuluh darah pada area terpasang seminosan (lengan kanan bagian atas). Subjek 1 dilakukan insersi seminggu dua kali setiap hari Senin pagi Kamis pagi dan menjalani, Hemodialisa selama 5 jam.

Nyeri dirasakan saat penusukan sampai berakhirnya hemodialisa, nyeri pada AV fistula dan sekitar area AV fistula. Selama menjalankan hemodialisa Subjek 1 tidak mengkonsumsi obat anti nyeri, mengatakan nyeri berkurang ketika istirahat, nyeri akan bertambah bila banyak bergerak dan aliran dialysis tidak lancar, nyeri terasa seperti di tusuk dan perih, nyeri yang di rasakan di sekitar tempat penusukan jarum, skala nyeri 3, dan nyeri hilang timbul hasil pengukuran Tekanan darah 135/85 mmHg, RR 19 $\mathrm{x} /$ menit, Suhu $36,7{ }^{\circ} \mathrm{C}$, dan Nadi $79 x$ /menit dan CTR $<3$ detik. Hasil Laboraturium : HB 7,2 gr/dl, Ureum 88 mgdl, Kreatinin 4,7 mgdl dengan EGFR 14.

Subjek II Setelah dilakukan wawancara dan pengkajian nyeri pada subjek II didapatkan hasil kesadaran komposmentis keadaan umum baik subjek II mengatakan menjalani hemodialisa semenjak 3 tahun yang lalu, sebelumnya 5 tahun yang lalu subjek mengalami peningkatan tekanan darah yang tidak teratur, subjek minum obat amlodifin $5 \mathrm{mg}$ bila pusing dan leher pegal - pegal, kontrol tidak teratur dan senang makan krupuk serta ikan asin terpasang seminosan. ditangan kanan atas. Subjek 2 dilakukan insersi seminggu dua kali pada hari Senin pagi dan Kamis pagi dan menjalani hemodialisa selama 5 jam.

Keluhan yang dirasakan saat ini badan lemas, kadang kadang terasa pusing, pucat (tidak ada), distensi vena jugularis (+), konjungtiva terlihat anemis, seklera anikterik, muka sembab, edema pada ektermitas bawah (+) kulit kering, bersisik dan kehitaman. BAK kurang dari $200 \mathrm{cc}$ perhari. Nyeri pada AV fistula dan sekitar area AV Fistula, nyeri dirasakan saat penusukan sampai berakhirnya hemodialisa. Selama menjalankan hemodialisa subjek 2 tidak mengkonsumsi obat anti nyeri atau obat hipertensi, subjek mengatakan nyeri berkurang ketika zikir istirahat, subjek 2 mengatakan nyeri bertambah bila banyak bergerak dan aliran dialysis tidak lancar, nyeri terasa seperti di tusuk jarum dan perih, nyeri yang di rasakan di sekitar tempat penusukan jarum, skala nyeri 3, dan nyeri hilang timbul hasil pengukuran tekanan darah 160/92 $\mathrm{mmHg}$, RR $20 \mathrm{x} /$ menit, Suhu $36,2{ }^{\circ} \mathrm{C}$, dan Nadi 93x/menit dan CTR $<3$ detik. Hasil Laboraturium : HB 8.00 gr/dl, Ureum 154 mgdl, Kreatinin 5,7 mgdl dengan EGFR 9. 


\section{Kondisi Setelah Diberikan Intervensi}

Tabel. 1

Skala Nyeri Sebelum dan Sesudah Intervensi Subjek 1

\begin{tabular}{ccc}
\hline Pertemuan & Sebelum & Sesudah \\
\hline 1 & Skala 3 & Skala 1 \\
2 & Skala 2 & Skala 0 \\
3 & Skala 3 & Skala 1 \\
4 & Skala 2 & Skala 0 \\
\hline
\end{tabular}

Subjek I dilakukan kompres $\mathrm{NaCl}$ 0,9\% selama 4 jam, dengan penggantian kompres setiap jam dan setiap 15 menit kain kasa di basahi dngan $\mathrm{NaCl}$ 0,9\% diisetiap jam di evaluasi skala nyeri, pada pertemua pertama dijam pertama rasa nyeri masih dirasakan dan belum terjadi penurunan nyeri, tetapi secara bertahap dijam-jam selanjutnya terjadi penurunan nyeri dari 3 menjadi dua dan terakhir kompres terjadi penurunan menjadi 1. Kompres ini dilakukan selama 4 kali pertemuan setiap hari Senin dan Kamis. Hasil pemberian kompres kompres pada subjek 1 terjadi perubahan kearaah yang lebih baik dibuktikan Subjek I tampak rileks dan nyaman, dapat mengikuti arahan, ekspresi wajah rileks, tidak tampak menahan nyeri, keluhan nyeri berkurang selama di kompres dengan $\mathrm{NaCl}$ 0,9\% dalam 4 kali pertemuan.

Tabel. 2

Skala Nyeri Sebelum dan Sesudah Intervensi Subjek 2

\begin{tabular}{ccc}
\hline Pertemuan & Sebelum & Sesudah \\
\hline 1 & Skala 3 & Skala 2 \\
2 & Skala 2 & Skala 1 \\
3 & Skala 3 & Skala 2 \\
4 & Skala 4 & Skala 2 \\
\hline
\end{tabular}

Subjek II bersedia dilakukan kompres $\mathrm{NaCl} 0,9 \%$ selama 4 jam dalam 1 sesi hemodialisa selama 4 kali pertemuan berturut-turut, dengan penggantian kompres setiap jam dan setiap 15 menit kain kasa di basahi $\mathrm{NaCl}$ 0,9\% disetiap jam di evaluasi skala nyeri, pada pertemuan pertama dijam pertama rasa nyeri masih dirasakan dan belum terjadi penurunan nyeri, tetapi secara bertahap dijam-jam selanjutnya terjadi penurunan nyeri dari 3 menjadi dua dan terakhir kompres terjadi penurunan menjadi 2. Kompres ini dilakukan selama 4 kali pertemuan setiap hari Senin dan Kamis. subjek II tampak nyaman, dapat mengikuti arahan, ekspresi wajah rileks, tidak tampak menahan nyeri, keluhan nyeri berkurang selama di kompres. Hasil pemberian kompres kompres pada subjek II terjadi perubahan kearaah yang lebih baik dibuktikan Subjek II tampak rileks dan nyaman, dapat mengikuti arahan, ekspresi wajah rileks, tidak tampak menahan nyeri, keluhan nyeri berkurang selama di kompres dengan $\mathrm{NaCl} 0,9 \%$ dalam 4 kali pertemuan. 


\section{PEMBAHASAN}

Gagal ginjal kronik (GGK) merupakan keruskaan fungsi ginjal permanen dimana ginjal tidak dapat membuang racun dan produk sisa dari dalam darah, ditandai adanya protein dalam urin serta penurunan laju filtrasi glomerulus, berlangsung lebih dari 3 bulan. Perjalalanan penyakit ini diawali dari pengurangan fungsi ginjal antara 30-50\%, pengurangan fungsi ginjal tidak mengurangi akumulasi sampah metabolik dalam darah karena nafron yang masih baik akan mengkompensasi nefron yang rusak, jika hal ini terus berlangsung mengakibatkan terus menurunnya fungsi ginjal hingga ke gangguan fungsi ginjal tahap akhir (Le Mone, 2016). Penyakit ginjal tahap akhir diperkirakan jumlah nefron yang rusak mencapai $90 \%$ dengan GFR hanya $10 \%$ sehingga fungsi ginjal tidak dapat dipertahankan, ginjal tidak mampu mempertahankan homeostasis, dapat dilihat dari hasil ureum kreatinin yang terus meningkat, adanya edema, gangguan keseimbangan elektrolit, asam basa dan akan mengganggu seluruh sistem tubuh.

Berdasarkan hasil wawancara subjek 1 telah menjalani hemodialisa selama 5 tahun dan subjek 2 selama 3 tahun dalam waktu tersebut masing - masing subjek selalu melakukan hemodialisa setiap hari Senin dan Kamis, dalam waktu tersebut pula subjek terpapar dengan rasa nyeri. Lamanya subjek terpapar dengan rasa nyeri menurut subjek mengakibatkan meningkatkan rasa takut akan nyeri saat akan dilakukan insersi AV fistula, hal ini sesuai dengan penelitian yang disampaiakan Wakhid $\mathrm{H}$, pengalaman masa lalu seseorang yang pernah mengalami insersi justru akan meningkatkan rasa nyeri. Menurut IGAPS Laksmi (2018) Pengalaman masa lalu seseorang yang pernah mengalami insersi justru akan meningkatkan rasa nyeri, semakin sering seseorang terpapar dengan nyeri maka semakin besar intensitas nyeri yang dirasakan

Berdasarkan rentang usia kedua subjek berada pada rentang usia 45-59 tahun, dimana Subjek I berusia 53 tahun dan Subjek II berusia 50 tahun. Menurut DepKes. (2018) pasien hemodialisis terbanyak adalah kelompok usia 45-64 tahun, baik pasien baru maupun pasien aktif, hal ini sesuai juga dengan penelitian Agustina (2019) berdasarkan usia didapatkan kelompok usia terbanyak adalah 40-60 tahun sebanyak 65 pasien $(62,5 \%)$, diikuti kelompok usia <40 tahun sebanyak 23 pasien $(22,1 \%)$, dan >60 tahun sebanyak 16 pasien $(15,4 \%)$.

Subjek II menderita gagal ginjal akibat dari penyakit Diabetus Millitus yang dideritanya sejak 15 tahun yang lalu, penelitian ini sesuai dengan data yang dikumpulkan oleh Indonesia Renal Registry (IRR), pada tahun 2007-2008 didapatkan penyebab tersering kedua pada gagal ginjal kronis adalah diabetes melitus (23\%). Crandall \& Shamoon (2016) mengungkapkan salah satu penyebab utama terjadinya gagal ginjal adalah nefropati diabetik akibat dari penyakit diabetes melitus yang tidak terkontrol.

Pada penelitian ini ngin mengetahui manfaat dari kompres $\mathrm{NaCl} 0,9 \%$ terhadap penurunan intensitas skala nyeri yang dilakuka pada Subjek I dan subjek II. Sekala nyeri dinilai sebelum dan sesudah dilakukan intervensi. Subjek yang dilakukan intervensi adalah pasien gagal ginjal kronis yang menjalani hemodialisa dengan insersi AV fistula dan mengalami nyeri. Menurut LeMone \& Bauldof (2016) dalam upaya mengatasi nyeri tersebut terdapat beberapa cara nonfarmakologis yang dapat digunakan seperti teknik relaksai, distraksi, stimulasi, imajinasi terbimbing, hipnosis dan kompres, manfaat kompres dapat menurunkan prostaglandin, yang memperkuat sensitivitas reseptor nyeri dan subkutan lain pada tempat cedera dengan menghambat proses inflamasi. 
Dalam penelitian ini Subjek I dan II mendapat terapi kompres $\mathrm{NaCl} \mathrm{0,9 \%} \mathrm{selama}$ 4 jam dari proses hemodialisa yang berlangsung lima jam. Saat berlangsungnya hemodialisa dalam 1 kali pertemuan kompres dilakukan selama 4 jam, setiap jam nyeri dinilai, di ganti kompresnya, dan setiap 15 menit dicek kelembapannya. Kompres diberikan mulai pukul 8.00 sampai pukul 12.00 wib tepatnya setelah di lakukan insersi Av Fistula. Selama di lakukan kompres terjadi penurun nyeri pada subjek I, nyeri yang dirasakan hilang secara bertahap selama empat jam pemberian kompres, begitu pula yang dilakukan oleh subjek II.

Subjek I dan subjek II diperlakukan dengan hal yang sama, selama pemberian kompres subjek 1 dan subjek 2 juga tidak terdapat tanda - tanda alergi seperti kemerahan, gatal dikarnakan cairan $\mathrm{NaCl}$ 0,9 \% merupakan cairan isotonic atau sama dengan cairan tubuh. Selama pemberian kompres subjek 1 terlihat nyaman, tidak ada keluhan nyeri bertambah, dan tidak ada gestur atau ekspresi yang menunjukan menahan nyeri berat ketika dilakukan kompres. Sedangkan pada subjek ke 2 pada hari pertama pemberian kompres jam kedua nyeri masih menetap, subjek terlihat meringis dikarnakan ketidak lancaran akses dan selanjutnya lancar, sehingga dapat disimpulkan keluhan nyeri yang di rasakan kedua subjek dari jam pertama hingga jam ke empat selalu mengalami penurunan skala nyeri. Penurunan skala nyeri setelah dilakukan intervensi dengan rata - rata penurunan nyeri pada subjek 1 sebesar $83 \%$ dan subjek 2 terjadi penurunan skala nyeri sebesar $42 \%$.

Kompres dingin merupakan metode yang menggunakan cairan atau alat yang dapat menimbulkan sensasi dingin pada bagian tubuh yang memerlukan. Pemberian kompres dengan NaCL ,9\% dipandang efektif dalam membantu mengendalikan nyeri, stimulasi dingin pada kulit akan menurunkan konduksi impuls serabut syaraf sensoris nyeri, sehingga rangsangan nyeri menuju hipotalamus akan dihambat dan diterima lebih lama (Evangeline, 2015).

$\mathrm{NaCl}$ 0,9\% juga merupakan cairan isotonis yang bersifat fisiologis, non toksik dan tidak menimbulkan hipersensitivitas sehingga aman digunakan untuk tubuh dalam kondisi apapun. Selain itu $\mathrm{NaCl} 0,9 \%$ memiliki respon anti inflamasi sehingga dapat menurunkan gejala nyeri dan eritema yang timbul pada luka post insersi AV fistula sehingga rasa nyeri yang dialami subjek I dan subjek II berkurang. Mekanisme lain yang mungkin bekerja adalah persepsi dingin $\mathrm{NaCl} 0,9 \%$ menjadi dominan dan mengurangi persepsi nyeri. Penelitian ini sesuai dengan penelitian Evangeline (2015) yang menyatakan kompres Nacl $0,9 \%$ efektif untuk mengurangi nyeri pada pasien plebitis. Selain itu Teorigate kontrol menyatakan stimulasi kulit mengaktifkan transmisi serabut saraf sensori A-beta yang lebih besar dan lebih cepat. Proses ini menurunkan transmisi nyeri melalui serabut $\mathrm{C}$ dan delta-A berdiameter kecil sehingga gerbang sinap menutup transmisi impuls nyeri. Kompres dingin menimbulkan efek analgetik dengan memperlambat kecepatan hantaran saraf sehingga impuls nyeri yang mencapai otak lebih sedikit. Mekanisme lain yang mungkin bekerja adalah rasa dingin mendominan dan mengurangi persepsi nyeri, selain itu kompres dingin menyebabkan vasokontriksi pembuluh darah sehingga menimbulkan efek baal atau mati rasa pada kulit yang menimbulkan mati rasa/ baal, kompres dingin merupakan alternatif pilihan yang alamiah dan sederhana yang dengan cepat mengurangi rasa nyeri selain dengan memakai obat-obatan (Potter et al., 2017).

Pemberian kompres dingin terhadap intensitas nyeri pada saat insersi jarum pada pasien gagal ginjal yang menjalani hemodialisa rutin lebih efektif dalam menurunkan persepsi nyeri. 
Hasil penelitian terhadap dua subjek yang dilakukan pemberian kompres $\mathrm{NaCL}$ $0,9 \%$ selama empat kali pemberian dengan lama masing masing tindakan selama 4 jam terdapat penurunan skala nyeri yang berbeda. Terdapat perbedaan sekala nyeri sebelum dan sesudah pemberian kompres $\mathrm{NaCl} 0,9 \%$. Pada subjek 1 setelah dilakukan sebanyak 4 kali terdapat penurunan nyeri dengan rata- rata $83 \%$ sedangkan pada subjek 2 dengan waktu dan jumlah yang sama didapat penurunan nyeri rata- rata $42 \%$.

\section{SIMPULAN}

Berdasarkan hasil penelitian dan pembahasan dapat dirumuskan simpulan sebagai berikut rasa nyeri pada subjek 1 setelah diberikan kompres NaCL 0,9\%, selama 4 kali pertemuan menunjukan penurunan skala nyeri hal yang sama juga terjadi pada subjek II setelah dilakuka kompres NaCL $0,9 \%$ terjadi penurunan.

\section{SARAN}

\section{Bagi Masyarakat}

Diharapkan masyarakat yang memiliki keluarga dengan penyakit gagal ginjal kronis dengan hemodialisa yang setelah dilakukan penusukan AV Fistula mengalami nyeri khususnya subjek I dan subjek II untuk mengerti dan menerapkan kompres $\mathrm{NaCl}$ $0,9 \%$ saat di lakukan hemodialisa.

\section{Bagi Intitusi Pendidikan}

Hasil penelitian ini dapat dijadikan bahan informasi pendidikan sehingga saat mahasiswa melakukan terapi untuk menurunkan persepsi nyeri maka dapat diterapkan terapi kompres $\mathrm{NaCl} 0,9 \%$.

\section{Bagi Pelayanan Kesehatan}

Pelayanan kesehatan masyarakat seperti rumah sakit dan instansi kesehatan lainnya hendaknya mengaplikasikan kompres $\mathrm{NaCl} 0,9 \%$ dalam upaya menurunkan persepsi nyeri pada klien yang mengalami nyeri setelah di lakukan penusukan pada AV Fistula. Maka perawat juga dapat memberikan terapi kompres $\mathrm{NaCl} 0,9 \%$ untuk mengurangi persepsi nyeri yang di rasakan klien.

\section{Penelitian Selanjutnya}

Penelitian ini dapat dijadikan referensi bagi peneliti selanjutnya untuk dapat melakukan penelitian yang terkait dengan kompres $\mathrm{NaCl} 0,9 \%$ dalam upaya menurunkan persepsi nyeri pada klien yang mengalami nyeri setelah di lakukan penusukan pada AV Fistula dan diharapkan peneliti selanjutnya dapat melakukan penelitian lebih lanjut tentang terapi kompres $\mathrm{NaCl} 0,9 \%$ dalam upaya menurunkan persepsi nyeri pada klien yang mengalami nyeri setelah di lakukan penusukan pada AV Fistula dengan responden lebih banyak.

\section{DAFTAR PUSTAKA}

Agustina, W., \& Wardani, E. K. (2019). Penurunan Hemoglobin pada Penyakit Gagal Ginjal Kronik setelah Hemodialisis di RSU KH Batu. Jurnal Ners dan Kebidanan, 6(2), 142-147. DOI: 10.26699/jnk.v6i2.ART.p142-147

Crandall, J., \& Shamoon, H. (2016). Diabetes mellitus. Dalam: Goldman L, Schafer AI, penyunting. Goldman-Cecil Medicine. Edisi ke-25. Philadelphia: Elsevier Saunders. hlm. 1542-48 
Djarwoto, B. (2018). Pelatihan Dialisis Perawat RSUP Dr. Sardjito Yogyakarta. Yogyakarta: IP2KSDM RSUP Dr. Sardjito

Evangeline, H. (2015). Perbedaan Kompres $\mathrm{NaCl}$ 0,9\% dan Alkohol 70\% terhadap Penurunan Intensitas Nyeri pada Pasien Pleblitis. Jurnal Kedokteran dan Kesehatan, 2(03). Diakses https://ejournal.unsri.ac.id/index.php/jkk/article/view

Endiyono, E. (2017). Pengaruh Kompres NaCl terhadap Tingkat Persepsi Nyeri Insersi AV Fistula pada Pasien Hemodialisa di Rumah Sakit Umum Daerah Purbalinga. Jurnal Medika Respati, 12(3). Di akses tanggal 12 Mei 2018

Fauji, A. (2018). Kompres Es Lebih Efektif untuk Mengurangi Nyeri saat Insersi Jarum pada Pasien Hemodialisa: EBN. Majalengka: Jurnal Keperawatan dan Kesehatan Medisna Akper YPIB Majalengka. IV(7). http://ejournal.akperypib.ac.id/wpcontent/uploads/2018/03/MEDISINA-Jurnal-Keperawatan-dan-Kesehatan-AkperYPIB-Majalengka.pdf

Indonesia Renal Registry (IRR). (2016). Report of Indonesian Renal Registry, $9^{\text {th }}$ Edition. Jakarta: Perkumpulan Nefrologi Indonesia (Pernefri)

Indonesia Renal Registry (IRR). (2017). Report of Indonesian Renal Registry, $10^{\text {th }}$ Edition. Jakarta : Perkumpulan Nefrologi Indonesia (Pernefri)

Kemenkes RI. (2018). Cegah dan Kendalikan Penyakit Ginjal dengan Cerdik dan Patuh. http://sehatnegeriku.kemkes.go.id/baca/rilis-media/20180307/1425164/ cegah-dan-kendalikan-penyakit-ginjal-cerdik-dan-patuh

Laksmi, I. G. A. (2018). Pengaruh Kompres Dingin terhadap Tingkat Nyeri saat Pemasangan Infus pada Anak Usia Sekolah Diakses dari: file://C:/Users/akper/Downloads/35-Article\%20Text-61-2-10-20200310.pdf

LeMone, B., \& Bauldoff, B. (2016). Buku Ajar Keperawatan Medikal Bedah Gangguan Sistem Perkemihan. Jakarta: EGC

Manus, S., Moeis, E., \& Mandang, V. (2015). Perbandingan Fungsi Kognitif Sebelum dan Sesudah Dialisis pada Subjek Penyakit Gagal Ginjal Kronis yang Menjalani Hemodialisis. Jurnal E-Clinic (Ecl), 3(3), 816-81

National Kidney Foundation. (2015). About Chronic Kidney Disease. Diakses dari: https://www.kidney.org/kidneydisease/aboutckd

Padila, P. (2012). Buku Ajar Keperawatan Medikal Bedah. Yogyakarta: Nuha Medika

Pranowo, S., Prasetyo, A., \& Handayani, N. (2016). Pengaruh kompres Dingin terhadap Penurunan Nyeri Pasien saat Kanulasi (Inlet Akses Femoral) Hemodialisis. Cilacap. Jurnal Kesehatan Al-Irsyad (IKA)IX(2). Diakses dari: https://www. google.com/ search?Clie nt=firefox-b-d\&sxsrf

Potter, P. A., Perry, A. G., Stockert, P. A., \& Hall, A. M. (2017). Fundamentals of Nursing. ed.St. Louis, Missouri: Elsevier Mosby

Riskesdas. (2018). Riset Kesehatan Dasar. http://www.depkes.go.id/resources/do wnload/general/Hasil\%20Riskesda \%202013.pdf

Wijaya, A., \& Padila, P. (2019). Hubungan Dukungan Keluarga, Tingkat Pendidikan dan Usia dengan Kepatuhan dalam Pembatasan Asupan Cairan pada Klien ESRD yang Menjalani Terapi Hemodialisa. Jurnal Keperawatan Silampari, 3(1), 393404. https://doi.org/https://doi.org/10.31539/jks.v3i1.883 